
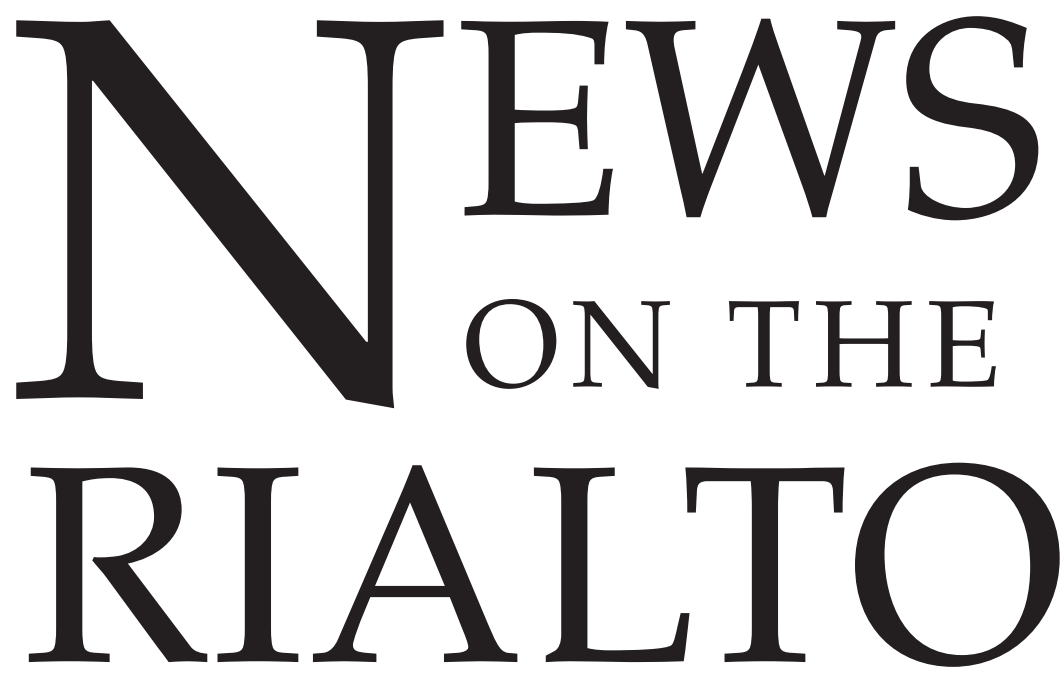

NEWSLETTER FOR VENETIAN STUDIES 


\section{A Gem Hidden Under the Dust of Centuries: The State Archive in Zadar}

At the eastern shore of the Adriatic lies an archive with holdings of considerable richness. The Croatian State Archive of Zadar (Državni Arhiv u Zadru, DAZD) is the main archive for Venetian, French and Habsburg Dalmatia. The State Archive of Zadar offers a broad range of research possibilities and allows insight into the complex history of both urban and rural Dalmatia.

Holdings from the period before 1797 The State Archive in Zadar contains not only various collections pertaining to the city of Zadar, but also to many other places in Dalmatia, from Korčula in the south to the Kvarner Islands in the north. The Archive itself was created in the year 1624, albeit most of the communal archives were transferred only after the end of Venetian rule. Among these are the communal archives of Rab, Šibenik, Trogir, Split, Hvar and Korčula. The state and richness of these communal archives varies greatly. In general, it may be perceived that the second Venetian takeover at the beginning of the 15 th century corresponds to an increase in the archival material preserved in the case of several cities.

These communal archives show signs of having suffered damage on frequent occasions throughout history. For instance, the archive of the commune of Hvar contains very little material predating the Ottoman raid of 1571. Others like the archives of Split and Korčula offer extensive evidence for earlier periods. For the city of Zadar there is no single communal archive, as the archival holdings have been organized into single collections according to respective communal authority. Among the oldest holdings are the archives of the Benedictine monastery of Sv. Krševan in Zadar as well as the archive of the diocese of Skradin.

Also, the quality of the inventories relating to each archive varies greatly. Whilst there are relatively new inventories for some holdings, such as the communal archive of Trogir, other in-

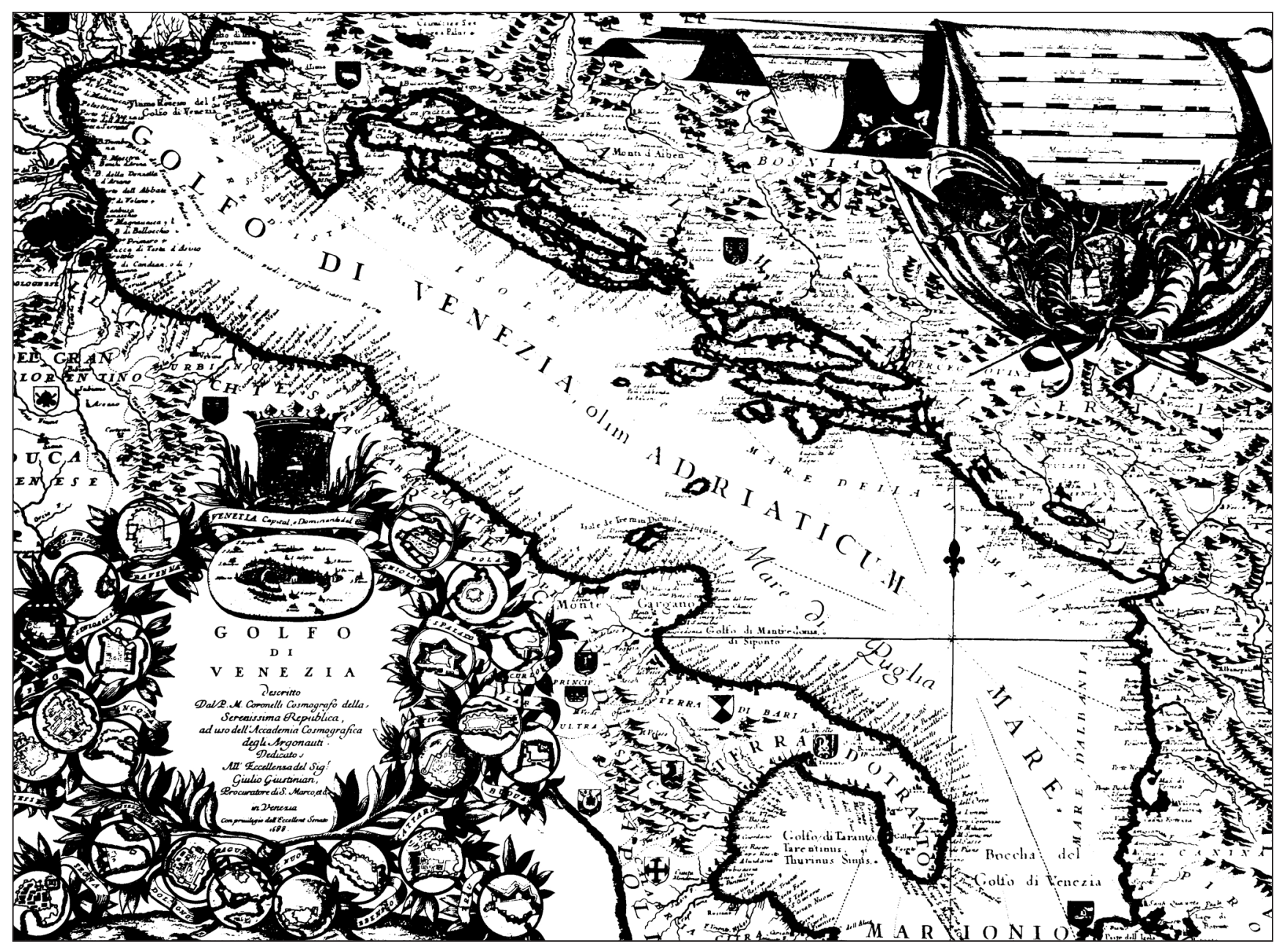


ventories still date from the first half of the 20th Century. In general, it can be assumed that the communal archives are all organized chronologically, a fact that greatly facilitates research.

Whereas communal archives in Dalmatia usually contain notary records, this is not the case for those of Rab, Pag, Zadar, Skradin, Šibenik and Split. For these cities the records have been organized into separate collections, dating from the 12th century (Rab) to 1797. The archives of Venetian provincial officials also form part of the holdings of the State Archive in Zadar. Among these are the archives of the Provveditore Generale in Dalmazia ed Albania (1597-1797), the Sindici Inquisitori in Dalmazia ed Albania (1748-1795) and the Sindici Avogadori (1420-1621). In addition, various familial archives contain material relating primarily to Zaratine families.

Furthermore, the records of brotherhoods, organizations similar to the scuole in Venice, contain material from the fifteenth to the twentieth century. Records of civil status for the period 1565 to 1943 were centralized in the Archive. In this regard it is worth noting that many Dalmatian parishes may have retained some records and historical documents, usually dating from the sixteenth century or later. The Archive also possesses a notable collection of maps and plans. The most interesting among them are certainly the Venetian cadastre (1597-1797), of which both maps and register books are preserved.

\section{Holdings from the period after 1797}

The majority of the holdings of theZadar State Archive date from after the fall of the Venetian Republic in 1797. As in other archives, this period offers a very broad variety of collections created under six different rulers. Among these are the archives of the French rulership (1806-1813), when Dalmatia was part of the Illyrian Provinces, and the archives of the first and second Habsburg rulerships (1797-
1805/1813-1918), when the Kingdom of Dalmatia was a part of the Danube Monarchy. Due to the fact that the city of Zadar was part of Italy between 1918 and 1943, the collections for this time contain the archive of the Italian administration, yet also the archives of the then Yugoslav communes which belong now to the county of Zadar. Interestingly, the archive of the Yugoslav consulate in Zadar (1921-1941) is also part of these holdings. There is a wide variety of holdings relating to the Yugoslav period (1943-1991), including communal archives, the archive of the communal hospital and the records of local schools and social and cultural institutions and associations, such as the Matica Dalmatinska (1863-1927) and the Teatro Verdi (1865-1944). Company archives, particularly from socialist times, are also part of the Archive's holdings. The most notable among them is the archive of the Maraschino Factory "Francesco Drioli" (1768/1823-1943).

\section{Practical Work in the Archive and the State of the Collections}

Our research is based upon the communal archive of Korčula, which is also preserved in the Croatian State Archive in Zadar. In total the communal archive of Korčula contains 560 archival units, amounting to a grand total of 81 running meters, with material dating from 1338 to 1797 . Boxes 6 to 36 contain records from the period between the takeover by the Venetian administration in 1420 and the end of the 15 th century. Unfortunately, the inventory for the archive of Korčula is slightly outdated. Practical work with the boxes has therefore to follow the physical organization of the documents. Similar to other fonds in the Archivio di Stato di Venezia, as for example the fonds of "Duca di Candia“, the communal archive of Korčula is divided into fascicles according to the communal institutions which produced them, namely the chancellery of the Comes (Cancellaria comitis), the fiscal chamber (Camera fiscalis) and the minor and the major court (Curia maior et minor). Documents emanating from the notaries of the city and island of Korčula were also incorporated into the archives.

Furthermore, the documents are usually ordered chronologically and collected as papers and fascicles according to their period of office of single Comites. This means that among the papers assigned to the tenure of a single Comes, one may find a wide variety of document types produced at roughly the same time by communal institutions as well as by notaries. This offers the possibility of studying single boxes as a means of obtaining a temporal cross-section, a practical approach suiting the aims of our current project. When doing such a cross-section, various document types are considered.

Records of the city's council contain information regarding elections to communal office. Correspondence books consist of letters received from other Dalmatian cities and from central offices in Venice. Juridical records can be divided into criminal (Criminalia) and civil cases (Civilia), with major trials and lawsuits often kept as separate documents outside the regular fascicles. Petitions are also of great value, offering new insights into the political life of the commune. Accounting books and licenses in general, including export licenses, are also to be found. Among the notarial acts one finds contracts, testaments and procuratorial contracts (Procurae).

In terms of language, most older documents are composed in Latin. Over time the language changes gradually to the vernacular, which in this case is a Venetian dialect. This poses some interesting problems - particularly with regard to agriculture - as quite a few terms are far beyond the contents of any dictionary. 
The conservational condition of the papers varies greatly. While some fascicles are in a perfect state, others are in pitiful condition. Damage has mainly been caused by water and insects, often affecting only the first and last pages of a fascicle.

\section{Our Current Research}

For the past few years, we have spent a considerable amount of time conducting research in the State Archive of Zadar. Therefore we would like to use the occasion to shed some light on our current research and simultaneously give a few practical hints on research at the Archive.

We are currently working on our PhD-Projects on late medieval Dalmatia as members of the interdisciplinary Special Research Program "Visions of Community" at the University of Vienna, Austria. Our project part, entitled "Society, Statehood and Religion in Late Medieval Dalmatia" focuses on the island of Korčula during the 15 th and early 16 th centuries, thereby deliberately exploiting the richness of its communal archive in respect of the relevant period. As part of the interdisciplinary project "Visions of Community," our project centers on the manner in which late medieval communities functioned. This has the potential to reveal perceptions or visions of community.

The island of Korčula is of particular interest, because the source material preserved in the State Archive of Zadar encompasses not only the city, but the entire island. This offers the possibility of studying urban as well as rural life. Hence, Fabian Kümmeler studies rural communities on Korčula, in particular herdsmen, but also villagers like women and men engaged in farming, wine-growing and fishing, as well as rural noblemen. Using a microhistorical approach, he analyses how these rural communities functioned, how they envisaged their commonalities, and how conflicts were mediated in ru- ral areas. At the same time, Kümmeler contextualizes his analysis against the background of the multi-layered social, political, economic and juridical structures and dynamics that characterized the rural areas of Korčula, Venetian Dalmatia and the Eastern Mediterranean in the 15 th century. Sascha Attia focuses on the urban realm of Korčula, examining the formation and functioning of both normatively-defined communities and ones arising from a particular set of circumstances ("situational"). He addresses questions concerning social dynamics, conflict and cooperation, and examines the interactions of the city's inhabitants, predominantly patricians, as in the case study on the Obradi family below.

Thereby we both apply a microhistorical approach focusing on selected protagonists, their surroundings and their "Lebenswelt." The core supposition is that decisions of individuals also shape their surrounding world, more precisely that the social environment is shaped by the totality of individual decisions. Therefore, decisions and actions of individuals are at the heart of our research. By taking actions along customary patterns, or in other words, along their particular "visions of community," individuals actively perpetuated the existence of their social environment. To put this into an individual perspective: individuals acted according to their own beliefs and conscience, i.e. their individual "Lebenswelt," and thus formed their social environment.

This, however, does not mean, that we are not interested in the wider social environment of the individuals concerned. As previous studies in respect of the Venetian Stato da Mar have generally been conducted from a Venetian and mostly normative perspective, we aim simply to complement the image by adding two studies from a very much individual and practical point of view.
In practical terms, this means that we have chosen a set of protagonists whom we follow over several decades. Clearly, the overall goal of our studies is not to achieve representativity but exemplarity with regard to the statics and dynamics of society. Our studies are aimed at complementing the research on the normative and legal framework of urban as well as rural societies and to deliver new insights by raising (and hopefully answering) questions on institutional, legal and social practice from an individual perspective. Therefore our research encompasses a broad range of topics and sources, from legal aspects to economic questions and social issues.

Overall, the most interesting cases encountered in the course of our research are those in which an individual's "Lebenswelt" departed from the common ground. In other words, situations in which individuals took actions and decisions which disrupted social norms and patterns. Precisely in these incidents, the aforementioned tensions between individual interests and social restrictions become visible. This leads to core questions on how conflict and cooperation helped shape communities. For our research, the dynamics of conflict and cooperation and its impact on ostensibly inalterable rules and forms of organization are of great interest.

In a recent paper, we examined a prison break in Korčula and its social, political and jurisdictional impact on the island's commune. Thereby we could rely on studies conducted by Oliver Jens Schmitt, who investigated socio-political, economic and ecological patterns on the Island of Korčula and with whom we work together closely on our project.

In late October 1461, the patrician Ser Franciscus de Obradi was freed from the city's prison in Korčula by two of his sons, who dug out a hole in the prison wall. Ser Franciscus de 
Obradi had been detained in Korčula at the demand of the Venetian Avogaria di Comun, and was supposed to be turned over to Venice subsequently. Anticipating such an event, the Venetian governor in Korčula issued a commination. According to this, any attempt to free Ser Franciscus from prison would be punished with a fine and penalized with a two-year-long banishment from the island.

In defiance of this punishment, two of his sons subsequently liberated their father from prison. Following the commination, investigations were carried out on this incident. These led ultimately to a criminal procedure being undertaken against the two sons of Ser Franciscus. In almost scenic descriptions, the reader learns of the patricians that gathered around the Comes in the loggia, the commune's officials that investigated the incident and the many different witnesses drawn from virtually all the city's social strata. In their testimonies these witnesses even describe the impact of conflict on their life and on their visions of community. In consequence, we were able to plunge into the life of Franciscus de Obradi and of numerous other individuals, and to examine the embossing force of conflicts for the commune and the different (situational) communities - not solely in its manifestation as prison break.

Embedded into the overall historical, political, economic and social processes, we were able to show how their self-interest made Ser Franciscus and his two sons turn against the interests of their commune and how they were excluded from the commune and banished from the island in consequence. Yet, just as much as it had an impact on the members of the Obradi family, this incident also left its mark on the local commune.
Državni Arhiv u Zadru

Address: Ruđera Boškovića bb, 23000

Zadar

Hours: M-F 8:30 to 14:00, W (except

from July and Aug) 8:30 to 18:30

Website: http://www.dazd.hr

Archival Information System: http:// arhinet.arhiv.hr

Telephone: +38523211530

Fax: +38523214908

Please note that photography in the Archive requires permission and is limited to 30 pictures per day and person. Also, the Archive charges a modest fee for its use.

For a complete overview over the holdings of Croatian Archives, see: Kolanović, Josip, Pregled arhivskih fondova i zbirki Republike Hrvatske, Zagreb 2006, 2. vols.

Also, Josip Kolanović and the Archive will publish an extensive two volume guide to the Archive: Kolanović, Josip, et. al. (eds.), Vodič državnog arhiva u Zadru, 2 vol., Zadar (in print).

\section{The VISCOM-Project}

The Vienna-based interdisciplinary research project "Visions of Community" (VISCOM) unites scholars from the fields of history and social anthropology, as well as tibetology and art history. Using a comparative approach, the project focuses on the visions of community and on the interaction of different communities between 400 and 1600. In five research projects, spanning from early medieval Europe and late medieval Central Europe and Dalmatia to South Arabia and Tibet, various forms of community are being studied. The Project is a cooperation of the University of Vienna together with the Austrian Academy of Sciences and funded by the FWF Austrian Science Fund.
The research team on late medieval Dalmatia is led by Oliver Jens Schmitt and focuses on Society, Statehood and Religion in Dalmatia in the 15th Century. Thereby the insular society of Korčula and the lives and actions of its inhabitants are at the core of research interest.

In consequence, the research for this article was carried out within the framework of SFB "Visions of Community," and was funded by the Austrian Science Fund (FWF): F4207-G18. Website: http://www.univie.ac.at/viscom/index_viscom.php?seite=dalmatia

\section{Publications include:}

Schmitt, Oliver Jens, Korčula sous la domination de Venise au 15e siècle (Paris, 2011), http://books.openedition.org/cdf/1501/.

Schmitt, Oliver Jens, "Storie d'amore, storie di potere. La tormentata integrazione dell'isola di Curzola nello Stato da mar in una prospettiva microstorica," in Venezia e Dalmazia (Venetiana 12), eds. Uwe Israel and Oliver Jens Schmitt (Rome, 2013), pp. 89-109.

Schmitt, Oliver Jens and Ortalli, Gherardo (eds.), Il 'commonwealth' veneziano tra 1204 e la fine della repubblica: identità e peculiarità (in print).

Kümmeler, Fabian and Attia, Sascha, "Der Strafe zum Trotz: Gemeinschaft und Konflikt im venezianischen Dalmatien. Ein Blick auf Korčula im 15. Jahrhundert," in Historicum - Zeitschrift für Geschichte (in print).

Sascha Attia and Fabian Kümmeler University of Vienna 